\title{
REVIEW
}

\section{Current Approaches to Pancreatic Cancer Screening}

\author{
Ankit Chhoda, ${ }^{*}$ Lingeng Lu, ${ }^{\dagger}$ Barbara M. Clerkin, ${ }^{\dagger}$ Harvey Risch, ${ }^{\dagger}$ and James J. Farrell ${ }^{\S}$
}

From the Yale Waterbury Internal Medicine Program, $*$ the Pancreatic Disease Program, ${ }^{\ddagger}$ and the Yale Center for Pancreatic Diseases,$^{\S}$ Yale School of Medicine, New Haven; and Chronic Disease Epidemiology ${ }^{\dagger}$ and the Yale Center for Pancreatic Diseases, "Department of Digestive Diseases, Yale School of Public Health, New Haven, Connecticut

\author{
Accepted for publication \\ September 26, 2018. \\ Address correspondence to \\ James J. Farrell, M.D., \\ Department of Digestive \\ Diseases, Yale School of \\ Medicine, LMP 1080, 15 \\ York St., New Haven, CT \\ 06510-3221. E-mail: james.j. \\ farrell@yale.edu.
}

\begin{abstract}
Pancreatic ductal adenocarcinoma (PDAC) has a 5-year survival rate of only $8 \%$ and is estimated to be the second leading cause of cancer-related deaths by 2021. Prior convention held that screening for PDAC would not be beneficial; however, a deeper understanding of the carcinogenesis pathway supports a potential window of opportunity among the target population. Screening for PDAC is not a standard practice among the general population because of its low incidence. However, screening may be beneficial for individuals with familial history, chronic diseases with genetic predispositions, or inherited cancer syndromes, such as hereditary breast ovarian cancer syndrome, hereditary pancreatitis, Peutz-Jeghers syndrome, familial atypical multiple mole melanoma, Lynch syndrome (hereditary nonpolyposis colorectal cancer), ataxia telangiectasia, and Li-Fraumeni syndrome, all of which have been associated with an increased risk of developing PDAC. The screening strategies among these high-risk individuals are targeted to identify precursor lesions and PDAC at an early resectable stage. This review describes the risk factors for pancreatic cancer, especially the genetic risk factors in high-risk individuals and current screening strategies available for PDAC. (Am J Pathol 2019, 189: 22-35; https:// doi.org/10.1016/j.ajpath.2018.09.013)
\end{abstract}

In the United States, pancreatic ductal adenocarcinoma (PDAC) is projected to account for approximately 55,440 incident diagnoses and 44,330 cancer-related deaths in 2018. ${ }^{1}$ The American Cancer Society has reported the 5-year survival proportion for PDAC to be only $8 \% .^{1}$ Over the past few decades, PDAC mortality has increased annually by $0.4 \%$ and is projected to rank second among causes of cancer-related deaths by $2021 .^{2}$ A potentially curative option for PDAC is surgical resection, which, along with combination chemotherapy, has been demonstrated to improve estimated 5-year survival to $21.1 \%$. $^{3}$ Most pancreatic lesions present at late stages after the cancer has spread, including regional spread $(29 \%)$ and distant metastasis $(52 \%){ }^{1}$

Prior convention held that screening for PDAC is not beneficial; however, a deeper understanding of the carcinogenesis pathway supports a potential window of opportunity among individuals at high risk of PDAC. The clonal evolution of fully transformed PDAC precursor lesions into infiltrating carcinoma occurs over some 11 years and metastasis occurs over an additional 6.8 years. ${ }^{4}$ This offers an opportunity to detect early PDAC lesions, especially precursor lesions, resulting from clonal expansion of pancreatic cells after acquisition of initiator mutations.

This article reviews risk factors for pancreatic cancer, especially diabetes mellitus, genetic risk factors in highrisk individuals (HRIs), and pancreatic cystic neoplasm precursors. Current screening strategies are also discussed.

\footnotetext{
Disclosures: None declared.

This article is a part of a review series on benign and neoplastic pancreatic lesions from their pathologic to molecular profiles and diagnoses.
} 
Table 1 Description of Various Genetic Syndromes Associated with PDAC

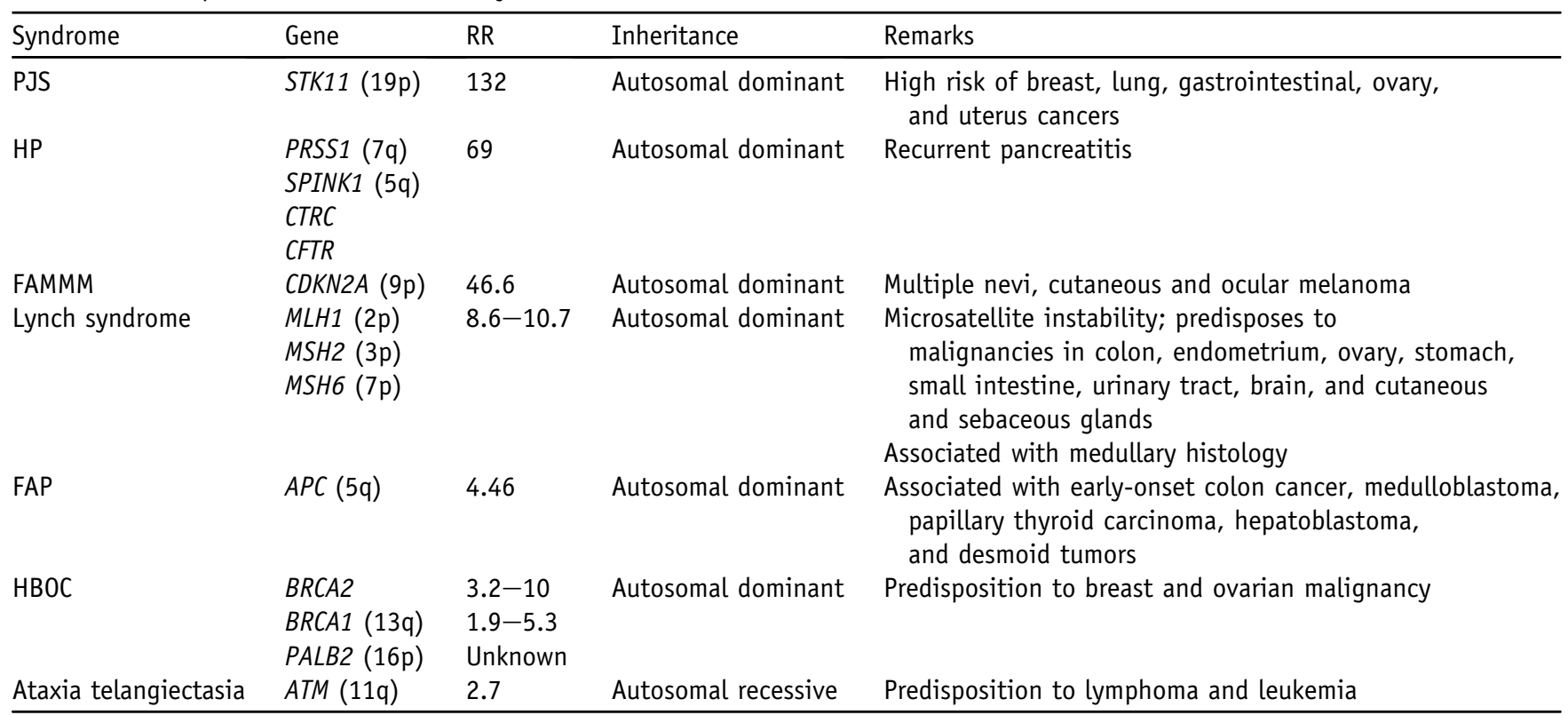

FAMMM, familial atypical multiple mole melanoma; FAP, familial adenomatous polyposis; HBOC, hereditary breast-ovarian cancer; HP, hereditary pancreatitis; PDAC, pancreatic ductal adenocarcinoma; PJS, Peutz-Jeghers syndrome; RR, relative risk.

\section{Risk Factors for Pancreatic Cancer}

Despite its aggressive nature and high degree of lethality, screening for PDAC is not standard practice among the general population because of its low incidence: individual lifetime risk is approximately $1.5 \%$ (National Cancer Surveillance Epidemiology and End Results Program, https:// seer.cancer.gov/statfacts/html/pancreas.html, last accessed October 10, 2018), and reliable, noninvasive screening tools are absent (population screening tests of such low lifetime risk require high sensitivity and particularly a specificity $>99 \%$ to avoid large numbers of false positives for each true positive found by the test). ${ }^{5}$ Hence, current screening strategies have largely focused on groups of individuals thought to be at increased risk of pancreatic cancer compared with the general population.

Perhaps $90 \%$ of pancreatic cancers are sporadic, but in some individuals, it can be attributed to familial aggregation (7\%), chronic diseases with genetic predisposition, or highrisk genetic syndromes (3\%). Such familial or genetic predisposition confers an elevated lifetime risk, generally at least fivefold relative risk of PDAC, and these individuals are classified as high risk (HRIs).

\section{Genetic Risk Factors}

Although many genetic defects likely remain unknown, several genetic syndromes associated with PDAC have been discovered. Because genetic syndromes can produce a variety of cancer types, individuals with genetic susceptibility may not have a family history specifically of PDAC.
The inherited cancer syndromes, such as hereditary breastovarian cancer syndrome, hereditary pancreatitis, PeutzJeghers syndrome, familial atypical multiple mole melanoma, Lynch syndrome (hereditary nonpolyposis colorectal cancer), ataxia telangiectasia, and Li-Fraumeni syndrome, have all been associated with increased risk of developing PDAC (Table 1). However, because of their rarity, they in total account for only a small fraction of PDACs.

\section{AB0 Blood Group}

The ABO blood group is a genetically defined factor that has been observed in more than two dozen studies since the 1960 s to be associated with risk of PDAC. In western countries, including the United States, the non-O ABO blood group is associated with approximately $40 \%$ increased risk $(95 \% \mathrm{CI}, 26 \%-57 \%){ }^{6}$ Because A, B, and $\mathrm{AB}$ blood groups in total compose approximately $56 \%$ of the population in the United States, the fraction of PDAC associated with non-O blood groups is nearly $20 \%$, comparable to the amount of PDAC attributable to cigarette smoking and double the amount of PDAC attributable to high-risk genetic mutations. ${ }^{6}$ The mechanism of how the $\mathrm{ABO}$ blood group is involved in the occurrence of PDAC is not known.

\section{Familial Pancreatic Cancer}

The term familial pancreatic cancer has been defined to apply to families with two or more first-degree relatives with PDAC. The family does not fulfill criteria for other known genetic syndromes. ${ }^{7}$ 
Familial pancreatic cancer risk stratification is based on the number of individuals with PDAC and their relationships to the proband. ${ }^{8}$ An elevated risk ratio of 32 -fold was found in individuals with three first-degree relatives (lifetime risk, $40 \%$ ), and an elevated risk ratio of 6.4-fold was found among individuals with two first-degree relatives (lifetime risk, $8 \%$ to $12 \%$ ). ${ }^{9}$ Also, a higher risk of PDAC has been observed among familial pancreatic cancer kindreds with younger-onset PDAC (age, $<50$ years; standardized incidence ratio $=9.3 \%) .{ }^{10}$

\section{Hereditary Breast-Ovarian Cancer Syndrome}

Hereditary breast-ovarian cancer syndrome involves drastically increased risk of ovarian and breast cancers secondary to germline mutations in the BRCA1, BRCA2, PALB2, and $A T M$ genes involved in DNA repair mechanisms. ${ }^{11}$ Increased breast and ovarian cancer risks are also associated with Fanconi anemia, including FANCC and FANCG genes. Germline mutations in these tumor suppressor genes also confer higher risks of pancreatic cancers (Table 1). ${ }^{12-15}$ Of the above mutations, BRCA2 has been one of the most commonly identified mutations, and its incidence among familial pancreatic cancer has been as high as $17 \% .^{16}$ Mutations in this gene impart a relative risk of 3.5 to 10 for development of PDAC. ${ }^{14,15}$ Mutations of BRCA2 are more common in individuals of Ashkenazi Jewish ancestry, who carry a single mutation, 6174delT, at a frequency of $1.3 \% .^{17}$

The BRCAl mutation, although less well identified, confers 2.5 to 3 times the risk of PDAC. ${ }^{16,17}$ Among $B R C A$ negative individuals, the partner and localizer of the $B R C A 2$ $(P A L B 2)$ gene is another DNA defect repair gene and also has been linked to the ATM gene. ${ }^{18}$ Although robust evidence through population studies is lacking, a sixfold higher risk of pancreatic cancer has been demonstrated among individuals with PALB2 mutations. ${ }^{19}$

\section{Familial Atypical Multiple Mole Melanoma}

Familial atypical multiple mole melanoma is caused by rare germline mutations in the tumor suppressor gene P16INK4A (alias $C D K N 2 A$ or multiple tumor suppressor gene). It has autosomal dominant inheritance with variable penetrance and is associated with multiple atypical nevi and malignant melanoma among individuals with one or more affected first- or second-degree relatives. Besides the risk of melanoma and nonmelanoma skin cancers, a relative risk 46.6 (95\% CI, 24.7-76.4) for PDAC has been observed among pl6 mutation carriers. ${ }^{20}$

\section{Lynch Syndrome}

Lynch syndrome is caused by defects in DNA mismatchrepair genes, including $M S H 2, M L H 1, M S H 1, M S H 2$, $P M S 2$, and EPCAM. Although this syndrome is generally associated with increased risk of colon cancer, a higher predisposition to pancreatic cancer has also been noted, with pancreatic tumors that have classical medullary appearances with lymphocytic infiltrates and microsatellite instability. ${ }^{21}$

\section{Peutz-Jeghers Syndrome}

Peutz-Jeghers syndrome results from rare mutations in the STK11/LKB1 tumor suppressor gene, with autosomal dominant inheritance. ${ }^{22}$ It is characterized by mucocutaneous pigmentations in the lips, buccal mucosa, and periorbital area. The germline defect predisposes to gastric, pancreatic, and small intestinal cancers and nongastrointestinal malignancies involving the breast, ovary, endometrium, cervix, and testis. The relative risk of PDAC in patients with Peutz-Jeghers syndrome is 132 -fold (95\% CI, 44-261-fold) compared with the general population and conveys a cumulative lifetime risk as high as $36 \%$ through the ages of 15 to 64 years. $^{23}$

\section{Familial Adenomatous Polyposis}

Familial adenomatous polyposis results from mutations in the $A P C$ gene, a tumor suppressor gene that codes for synthesis of scaffolding proteins for degeneration of $\beta$-catenin and also controls cell cycle progression and microtubule stabilization. ${ }^{24}$ Along with risk of colon cancers, familial adenomatous polyposis is associated with a 4.5- to 6-fold risk of PDAC.

\section{Ataxia Telangiectasia}

Ataxia telangiectasia occurs from defects in DNA repair due to mutation in the ATM gene. It is an autosomal recessive disorder, characterized by progressive neurologic abnormalities along with immune dysfunction and predisposition to lymphoma and leukemia, resulting from hypersensitivity to ionizing radiation. ${ }^{25}$ Monoallelic mutation in the ATM gene results in increased risk of breast cancer and doubled risk of PDAC in comparison with the general population. ${ }^{26}$

\section{Hereditary Pancreatitis}

Hereditary pancreatitis (HP) is a rare syndrome resulting in persistent pancreatic injury and inflammation from germline mutations in PRSS1, SPINK1, CTRC, and CFTR, genes with autosomal dominant inheritance and incomplete penetrance. ${ }^{27} \mathrm{HP}$ causes premature trypsin activation (PRSS1 mutation) or abnormal inhibitors (including chymotrypsin C-CTRC mutation or serine peptidase inhibitor-SPINK mutation). These mutations predispose to chronic pancreatitis and PDAC, with a standardized incidence ratio of $53 .{ }^{28}$ The CFTR mutation has also been associated with an early age of onset and a 5.3-fold increased risk of PDAC. ${ }^{29}$ 
Table 2 Current Indications for Pancreatic Cancer Screening in High-Risk Individuals

\begin{tabular}{|c|c|}
\hline Screening groups & Description \\
\hline $\begin{array}{c}\text { Familial pancreatic } \\
\text { cancer relatives }\end{array}$ & $\begin{array}{l}\text { 1. Aged }>55 \text { years, or } 10 \text { years younger than the age of youngest relative } \\
\text { with pancreatic cancer, and } \\
\text { 2. Come from a family with two or more members with a history of pancreatic cancer } \\
\text { (two of whom have a first-degree relationship consistent with familial pancreatic cancer), and } \\
\text { 3. Have a first-degree relationship with at least one of the relatives with pancreatic cancer. } \\
\text { If there are two or more affected blood relatives, at least one must be a first-degree relative of } \\
\text { the individual being screened. }\end{array}$ \\
\hline Hereditary pancreatitis & $\begin{array}{l}\text { 1. Hereditary pancreatitis with confirmed gene mutations that predispose to chronic } \\
\text { pancreatitis (eg, PRSS1, PRSS2, or } C T R C \text { ) and age } \geq 50 \text { years (these patients have an } \\
\text { estimated lifetime risk for pancreatic cancer of } 40 \% \text { ), or } 20 \text { years since their first attack } \\
\text { of pancreatitis, whichever age is younger. }\end{array}$ \\
\hline Peutz-Jeghers syndrome & $\begin{array}{l}\text { 1. At least } 30 \text { years old, and } \\
\text { 2. At least two of three criteria diagnostic of Peutz-Jeghers syndrome (characteristic intestinal } \\
\text { hamartomatous polyps, mucocutaneous melanin deposition, or family history of } \\
\text { Peutz-Jeghers syndrome), or } \\
\text { 3. Known STK11 gene mutation carrier. }\end{array}$ \\
\hline
\end{tabular}

The screening for pancreatic cancer is being performed at various centers as a prospective clinical trial (https://clinicaltrials.gov; trial identifier NCT02000089).

FAMMM, familial atypical multiple mole melanoma; HNPCC, hereditary nonpolyposis colorectal cancer.

\section{Nongenetic Risk Factors}

\section{Tobacco Exposure}

Tobacco exposure is one of the major modifiable risk factors associated with pancreatic cancers. PDAC has been associated with relative risks of 2 to 3 among cigarette smokers, with higher risks according to cumulative amount smoked and lower risks with increasing years quit. ${ }^{30}$ Cigarette smoking has been postulated to generate circulating carcinogens that cause pancreatic inflammation and mutations in protooncogenes (KRAS) and tumor suppressor genes $(p 53) .{ }^{31}$ Furthermore, smoking appears to interact with genetic predispositions, including HP and familial pancreatic cancer, to decrease age of onset of PDAC by 20 and 10 years, respectively, while increasing the risk by a factor of $2 .{ }^{32,33}$

\section{Alcohol Intake}

High alcohol intake has been associated with an increased risk of PDAC (relative risk, 1.15; 95\% CI, 1.06-1.25) in a recent meta-analysis. ${ }^{34}$ Although the pooled analysis demonstrated an increased risk of pancreatic cancer with high liquor intake (risk ratio, 1.43; 95\% CI, 1.17-1.74), little or no effect was revealed for what authors categorized as low or moderate drinking. ${ }^{34}$

\section{Diabetes Mellitus}

Diabetes mellitus (DM) appears to have a bidirectional association with PDAC. ${ }^{35}$ The onset of DM has been shown to precede occurrence of PDAC by a few years and resolve post-resection in many patients. ${ }^{36}$ PDAC seems to lead to DM through a paraneoplastic field mechanism, and this has been attributed to induced insulin resistance from pancreatic polypeptide deficiency ${ }^{37}$ or to adrenomedullin secreted in exosomes. ${ }^{38}$ Over the longer term, type $2 \mathrm{DM}$ is associated with approximately 1.5 -fold increased risk of PDAC. This has been attributed to growth stimulation by endogenous hyperinsulinemia. Increased risks attributed to obesity and metabolic syndrome are also thought to arise from elevated insulin levels. PDAC has also been associated with 


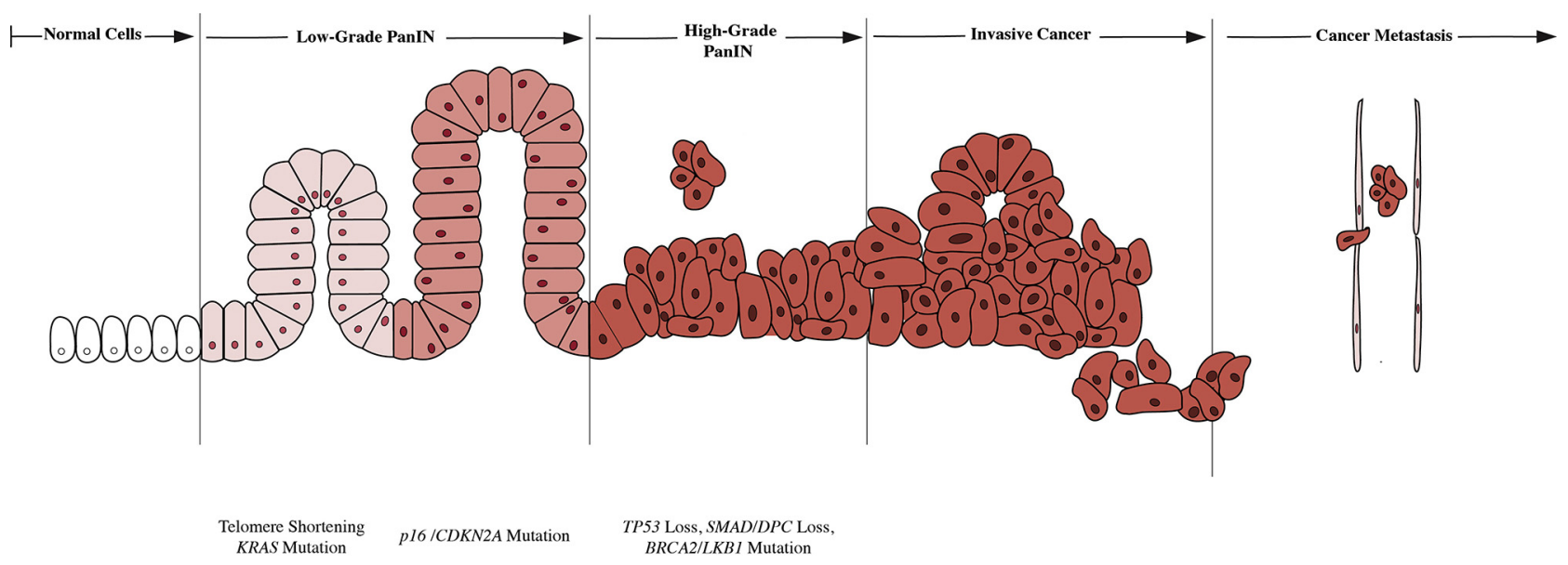

Figure 1 Model for pancreatic carcinogenesis displaying progression from normal cell to precursor lesions [pancreatic intraepithelial neoplasms (PanINs)], invasive cancer, and metastatic pancreatic cancer (based on original illustration by Bona Kim). Image created by D. Evan Kanouse and printed with permission.

pancreatogenous DM, with common predisposing risk factors leading to exocrine insufficiency. ${ }^{39}$ The DM-PDAC relationship is an intense area of research interest and has stimulated work to reduce knowledge gaps pertaining to interactions of chronic pancreatitis (CP), DM, and PDAC development. ${ }^{40}$ Surveillance strategies among these populations and the effect of DM treatment on PDAC are important questions, but no clear guidelines have been established yet.

\section{Chronic Pancreatitis}

$\mathrm{CP}$ is an established risk factor for pancreatic cancer. ${ }^{41}$ Chronic inflammation is believed to promote premalignant cell survival, autocrine stimulation of a protumorigenic environment, and desmoplasia. In a meta-analysis, progression of CP to PDAC occurred, on average, over one to two decades, and relative risk of PDAC was estimated at 13.3. ${ }^{42}$ Although only $5 \%$ of CP patients developed PDAC over two decades, the risk appeared to be much higher among patients with a hereditary predisposition. A recent cohort study reported an older age of onset and a substantial smoking history ( $>60$ pack-years) in a high proportion of patients with $\mathrm{CP} .^{41,43}$

\section{Screening and Surveillance for Pancreatic Cancer}

In 2011, the International Cancer of the Pancreas Screening (CAPS) Consortium held a conference, comprising multidisciplinary international experts, and formulated recommendations for screening, surveillance, and management of HRIs. ${ }^{44}$ The screening for pancreatic cancer is being performed at various centers as a prospective clinical trial (https://clinicaltrials.gov; identifier NCT02000089). Table 2 displays the various groups/cohorts under the CAPS5 study for PDAC screening among HRIs.

\section{Precursor Lesions}

Pancreatic cancer progression has been postulated to occur in a stepwise manner, starting from precursor lesions (Figure 1). ${ }^{45}$ Screening and surveillance strategies for HRIs are targeted to identify precursor lesions and PDAC at early and potentially resectable stages. The following three types of lesions have been considered precancerous or precursor lesions that can progress to invasive PDAC.

\section{Mucinous Cystic Neoplasms}

Mucinous cystic neoplasms (MCNs) are uncommon mucinproducing cystic neoplasms, with a reported prevalence of $23 \%$ in a database of individuals with resected pancreatic tumors. ${ }^{46}$ These lesions are much more likely to be found among middle-aged women; however, $1 \%$ to $8 \%$ of cases occur in men. MCNs are solitary lesions, mostly occurring in the body and the tail of the pancreas. They lack communications with pancreatic ducts and are morphologically distinct from other pancreatic precursor lesions. MCNs are characteristically defined by ovarian-like stroma and mucinproducing epithelium and are graded on the basis of cellular atypia and architectural distortion. MCNs have distinct demographic profiles and are unlikely to recur after resection. Given their generally young age at discovery, MCNs are managed by surgical resection and have almost $100 \%$ 5 -year survival afterward. ${ }^{47}$

\section{Intraductal Papillary Mucinous Neoplasms}

Intraductal papillary mucinous neoplasms (IPMNs) are mucin-producing epithelial neoplasms that originate from the main pancreatic duct, its contributing branches, or possibly mixed origins. Microscopically, IPMN cells have papillary projections and lack ovarian-like stroma, unlike MCNs. 
Main duct IPMNs have a higher predisposition for malignant transformation, compared with branch duct IPMNs, as demonstrated in a longitudinal study in which the 5-year actuarial risk of progression to high-grade dysplasia among main duct IPMNs was of $63 \%$, in contrast to $15 \%$ in the branch duct IPMNs $(P<0.001){ }^{48}$

IPMN lesions are further stratified on the basis of highrisk stigmata or worrisome features (WFs). High-risk stigmata includes cysts accompanying obstructive jaundice, those with enhancing mural nodules $>5 \mathrm{~mm}$, or those with a main pancreatic duct size $>10 \mathrm{~mm}$ in longest dimension. ${ }^{49}$ WFs include cysts $>3 \mathrm{~cm}$, enhancing mural nodules $<5 \mathrm{~mm}$, thickened/enhancing cyst walls, main duct size of 5 to $9 \mathrm{~mm}$, abrupt change in caliber of pancreatic duct with distal pancreatic atrophy, lymphadenopathy, increased serum level of carbohydrate (or cancer) antigen $19-9$, or cyst growth rate $>5 \mathrm{~mm} / 2$ years or $>10 \mathrm{~mm}$ during follow-up. ${ }^{50,51}$

\section{Pancreatic Intraepithelial Neoplasms}

Pancreatic intraepithelial neoplasms (PanINs) are microscopic flat or papillary lesions, comprising cuboidal or columnar cells that originate from pancreatic ducts. ${ }^{52}$ They have variable mucin content and cellular or architectural atypia, by which they are graded. These lesions are graded on the basis of atypia, and early lesions have a different immunohistochemical profile in comparison with advanced lesions. PanINs also display variable genetic alterations with progression of the dysplasia. Although they are potential targets of screening and intervention, progress is limited in accurate detection of PanINs in asymptomatic subjects through cross-sectional imaging and endoscopic ultrasound (EUS). PanINs are associated with focal lobular centric atrophy of the pancreatic parenchyma from surrounding fibrosis around mucinous metaplastic acinar cells. $^{53}$

\section{Age of Initiation and Termination of Screening}

Individuals with a lifetime risk of pancreatic cancer of $>5 \%$ should consider screening for the disease or its precursors. With present technologies, population-level screening in general is unwarranted. However, individuals who know of their high familial, genetic, or epidemiologic risks should consult with health care providers for consideration of the pros and cons of screening, because a much higher risk of screening false positivity than actual detection will ensue for lifetime risks of $<15 \%$. Once screening is chosen, the age to start is a critical parameter for both detection of precursor lesions in a timely manner and health costs and psychological stress among HRIs. The average age of diagnosis of PDAC among individuals with familial PDAC is 68.18 years, but genetic anticipation results in earlier age of onset in successive affected generations. ${ }^{10}$ The CAPS Consortium recommends screening for familial PDAC beginning at the age of 50 years. ${ }^{44}$ However, most programs have initiated screening at the age of 40 years, or 10 years before the youngest age of onset for PRSS1 mutation carriers with $\mathrm{HP},{ }^{54}$ and at the age of 30 years among patients with PJ syndrome, given the younger ages of onset in this high-risk subset.

\section{Imaging Modalities for Screening}

PDAC lesions can be detected through various imaging modalities. As a staging modality, computed tomography enables accurate assessment of PDAC resectability and visualization of the upper abdomen. ${ }^{55}$ However, as a surveillance tool, it has low accuracy in detection of small PDAC lesions and carries some risks associated with radiation exposure. Positron emission tomography-computed tomography is another imaging modality that enables the differentiation of a hypermetabolic state of a neoplasm or precursor lesions versus nodularity associated with chronic pancreatitis. ${ }^{56}$ The cost of positron emission tomography-computed tomography is high, and its sensitivity is not high enough.

Most centers use magnetic resonance imaging (MRI) and EUS in the detection of small asymptomatic pancreatic lesions. MRI has the benefits of no radiation exposure and helps in better characterization of pancreatic cysts. In conjunction with MR cholangiography, MRI achieves a fairly high diagnostic accuracy (84\% sensitivity and $97 \%$ specificity) for PDAC detection. ${ }^{57}$ This is significant because many of the early PDAC lesions have associated ductal or cystic changes rather than discrete masses.

Diffusion-weighted imaging represents an advancement in MRI and detects the brownian movements of water molecules. Factors influencing brownian motion and diffusion-weighted imaging include increased cell density, edema, fibrosis, and altered functionality of cellular membranes. ${ }^{58}$ The pooled sensitivity and specificity of diffusionweighted imaging for differentiating PDAC lesions from noncancerous masses are 0.91 (95\% CI, 0.84-0.95) and 0.86 (95\% CI, 0.76-0.93), respectively. ${ }^{59}$

EUS is another sensitive modality for PDAC screening without radiation exposure, but it has risks associated with patient sedation and interobserver variation can be higher than in other imaging modalities. ${ }^{60}$ Typical lesions seen in the pancreas in EUS imaging of the pancreas in high-risk individuals include pancreatic cysts and $\mathrm{CP}$-like changes in the parenchyma.

A prospective multicenter-blinded study evaluated the efficacy of MRI and EUS in detection of lesions among HRIs and demonstrated moderate (55\%) agreement in clinically relevant lesions. Both the modalities had good agreement in terms of lesion site (100\%) and size (Spearman coefficient, 0.83). ${ }^{61}$

The disagreement between modalities mostly involved detection of cystic lesions by EUS and solid lesions by MRI, thus supporting complementary use of both modalities. 
Table 3 Description of Various Screening Programs

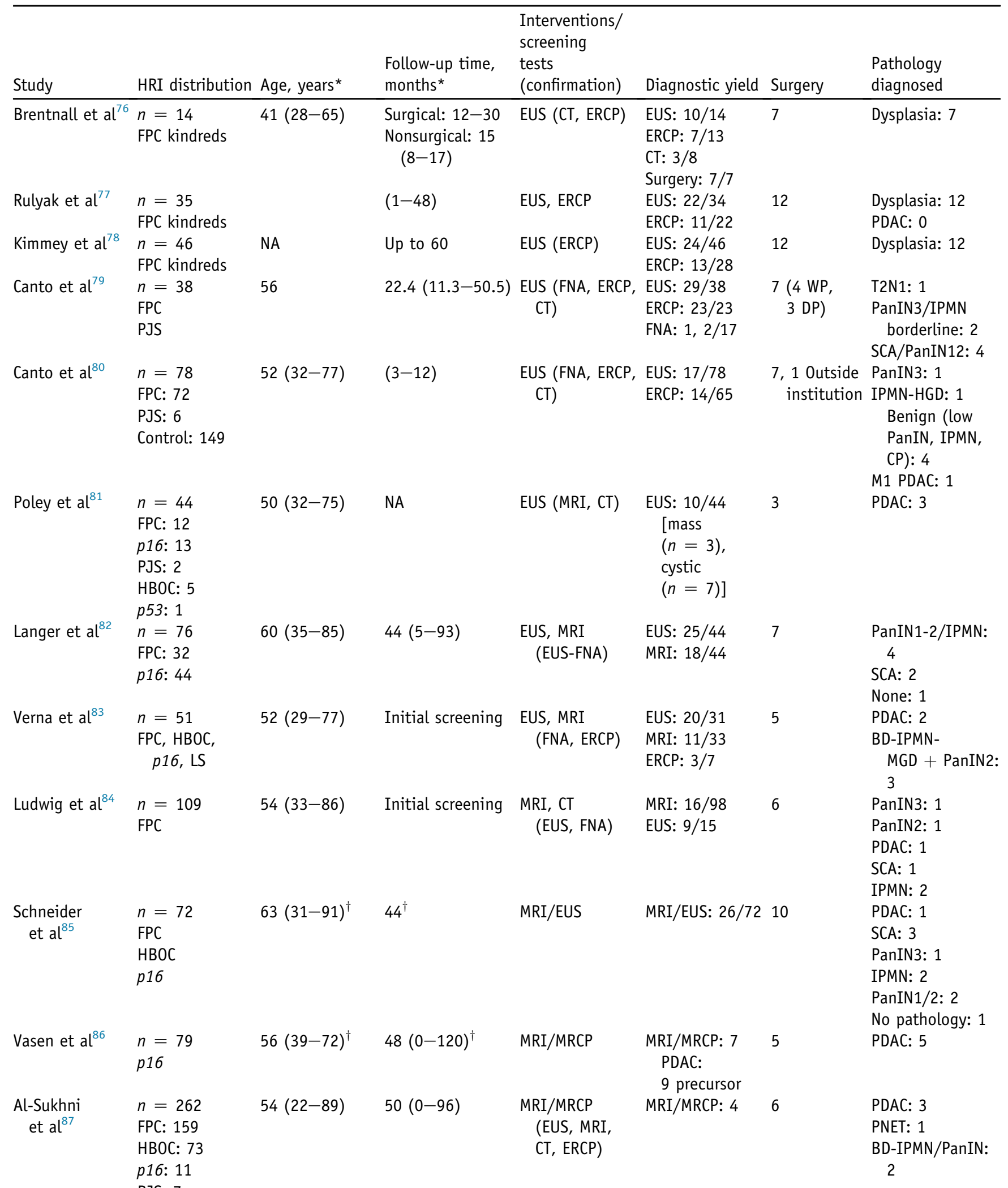

PJS: 7

HP: 2 
Table 3 (continued)

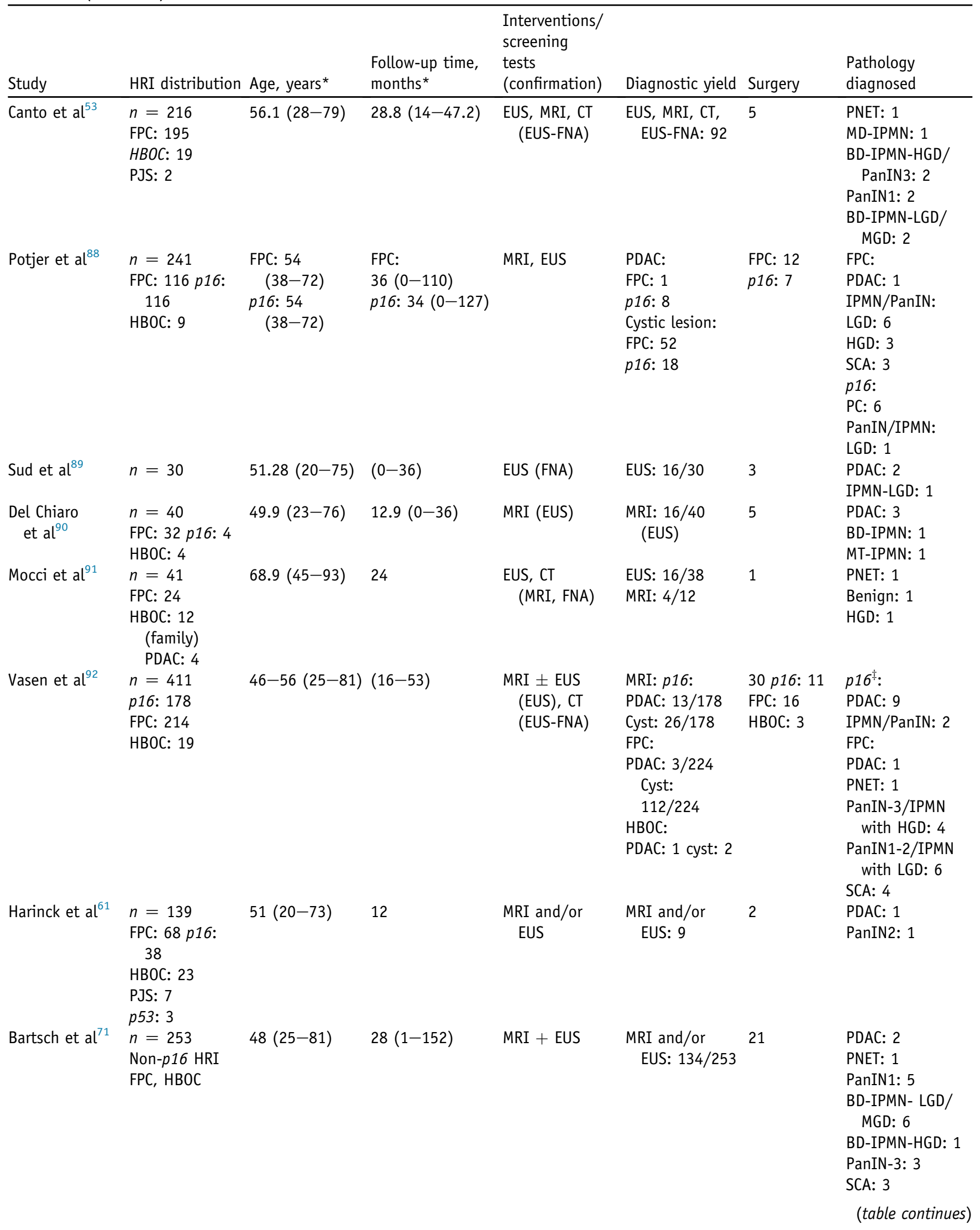




\begin{tabular}{|c|c|c|c|c|c|c|c|}
\hline Study & HRI distribution & Age, years* & $\begin{array}{l}\text { Follow-up time, } \\
\text { months* }\end{array}$ & $\begin{array}{l}\text { Interventions/ } \\
\text { screening } \\
\text { tests } \\
\text { (confirmation) }\end{array}$ & Diagnostic yield & Surgery & $\begin{array}{l}\text { Pathology } \\
\text { diagnosed }\end{array}$ \\
\hline Konings et $\mathrm{al}^{93}$ & $\begin{array}{l}n=186 \\
\text { FPC: } 98 \\
p 16: 53 \\
\text { HB0C: } 30 \\
\text { PJS: } 11 \\
\text { p53: } 4\end{array}$ & $52(19-75)$ & $44(0-120)$ & $\begin{array}{l}\text { MRI and/or } \\
\text { EUS }\end{array}$ & $\begin{array}{l}\text { MRI and/or } \\
\text { EUS: } 100 / 186\end{array}$ & 3 & $\begin{array}{l}\text { PDAC: } 2 \\
\text { PanIN2: } 1 \\
\text { MT-IPMN + MGD: } \\
\quad 1\end{array}$ \\
\hline
\end{tabular}

\footnotetext{
*Expressed as mean (range).

${ }^{\dagger}$ Central tendency is median, not mean.

${ }^{\ddagger}$ The 5 -year survival rate is $24 \%$.

$\mathrm{BD}$, branch duct; $\mathrm{CP}$, chronic pancreatitis; $\mathrm{CT}$, computed tomography; DP, distal pancreatectomy; ERCP, endoscopic retrograde cholagiopancreatography; EUS, endoscopic ultrasound; FNA, fine-needle aspiration; FPC, familial pancreatic cancer; HBOC, hereditary breast-ovarian cancer; HGD, high-grade dysplasia; HP, hereditary pancreatitis; HRI, high-risk individual; IPMN, intrapapillary mucinous neoplasm; LGD, low-grade dysplasia; M1, metastatic cancer; MD, main duct; MGD, moderate-grade dysplasia; MRCP, magnetic resonance cholangiopancreatography; MRI, magnetic resonance imaging; MT, mixed duct; NA, not applicable; $p 16, p 16 / C D K N 2 A$ mutation; $p 53$, individuals with $p 53$ mutation; PanIN, pancreatic intraepithelial neoplasm; PDAC, pancreatic adenocarcinoma; PJS, Peutz-Jeghers syndrome; PNET, pancreatic neuroendocrine tumor; SCA, serous cyst adenoma; WP, Whipple procedure.
}

\section{Biomarker Screening}

The only clinically established biomarker for PDAC is carbohydrate (or cancer) antigen 19-9, a sialylated Lewis blood group antigen expressed by some PDACs but not by normal tissue. ${ }^{62}$ Carbohydrate (or cancer) antigen 19-9 is used in the monitoring of disease progression and in response to chemotherapy. One study evaluated its accuracy in the general population and found both its sensitivity and specificity to be approximately $80 \%$ (95\% CI, 0.77-0.82). ${ }^{63}$ As such, carbohydrate (or cancer) antigen 19-9 by itself is inadequate for the detection of precursor lesions or early malignancy among normal individuals or in the general population. In addition, evidence is limited for its utility among HRIs.

Many novel blood biomarkers have also been examined, including circulating DNA testing for circulating miRNAs or exosomal markers for early PDAC diagnosis. miRNAs are 17- to 25-nucleotide noncoding RNAs that regulate gene function in the post-transcriptional stage by inhibition of mRNA translation or by facilitation of degradation. ${ }^{64}$ Among them, miR-21 has been the most studied, whereas other miRNAs, including miR-155, miR-196, and miR-210, have been consistently elevated in early PDAC ${ }^{65}$ Dysregulated expression of miR-21, miR-155, and miR-196 has also been observed in precursor lesions, like PanIN and IPMN.

Exosomal biomarkers are another class of molecular markers that comprise cell-secreted circulating extracellular microvesicles and their contents enclosed by bilayer membranes. They contain enriched biomaterials of protein, lipid, DNA, and RNA, which can be used as a diagnostic marker. A recent study demonstrated elevated exosomal miR-191, miR-21, and miR-451a among patients with PDACs compared with patients without disease. ${ }^{66}$ Moreover, circulating exosome-derived DNAs have been analyzed to demonstrate higher frequency of mutant KRAS in PDAC patients than among healthy individuals, although how far in advance of PDAC diagnosis such mutant KRAS could be detected remains unknown. ${ }^{67}$ Another recent study combined cell-free DNA mutations and circulating proteins for the detection of early pancreatic cancer. ${ }^{68}$ The test had sensitivities of $69 \%$ to $98 \%$ and a specificity of $>99 \%$ in PDAC diagnosis. This test required large blood samples, and its role in pancreatic cancer requires further validation in both the general population and HRIs.

\section{Pancreatic Juice and Pancreatic Cyst Biomarkers}

Given a high index of suspicion, precursor lesions not identified via imaging may be detected by analysis of pancreatic juice (aspirate from duodenum) or cyst fluid (obtained from pancreatic cysts). These fluids are rich in protein and DNA released from pancreatic neoplastic or precursor cells. ${ }^{69}$ These specimens, along with tissue samples from solid lesions, can be analyzed for genetic alterations, including KRAS mutations, gene mutations in pancreatic cysts, and loss of heterozygosity at $C D K N 2 A$, RNF43, SMAD4, TP53, and VHL. EUS-fine-needle aspiration accesses cyst wall and cyst fluid samples that can be sent for a range of studies, including molecular testing. The accuracy of these studies for identifying PDAC precursor lesions is uncertain, including in high-risk screening populations.

Analyzing pancreatic juice collected from the duodenum is another approach for screening otherwise asymptomatic patients considered to be at high risk of developing pancreatic cancer. Studies by Kanda et $\mathrm{al}^{70}$ collected secretin-stimulated pancreatic juice specimens and found GNAS mutations in $66 \%$ of IPMNs, which was concordant with fine-needle aspiration results. Higher TP53 mutation 
frequencies were found in advanced lesions, including PanIN-3s and IPMNs with high-grade dysplasia.

\section{Management of Detected Pancreatic Lesions}

As with many medical procedures in which experience improves outcomes, screening and subsequent management should, if possible, be obtained at high-volume centers with multidisciplinary teams. Lesions detected on imaging can undergo either observation or curative-intent resection. At present, most lesions in asymptomatic HRIs are not resected but kept under observation. ${ }^{53}$ For asymptomatic lesions among HRIs, the consensus is against total prophylactic pancreatectomy. $^{44}$

\section{Observation}

HRIs with no abnormalities are generally observed and undergo surveillance. The appropriate time interval for reimaging remains unclear. Although most of the members in the CAPS Consortium have favored a 12-month followup, such a consensus position was not evidence based. A recent study that included individuals at risk of familial pancreatic cancer found 24 months to be an optimal followup interval for individuals with unremarkable baseline imaging. ${ }^{71}$

\section{Surgery}

\section{Solid Lesions}

Although the empirical evidence is weak, it is recommended to confirm solid lesions detected by EUS or magnetic resonance cholangiopancreatography through pancreatic protocol computed tomography scans. Lesions $\geq 1 \mathrm{~cm}$ or detected on multimodalities may be considered for resection, but definite tissue diagnosis through biopsy is also recommended. ${ }^{44}$ The management of indeterminate solid lesions is not clear.

\section{Cyst Lesions}

Cystic lesions, including MCN and IPMN, are classified on the basis of consensus guidelines, which have been recently updated. $^{72}$ Symptomatic cysts (associated with pain, pancreatitis, or jaundice) and those with high-risk stigmata (cysts with obstructive jaundice, enhancing mural nodules $>5 \mathrm{~mm}$, or in the main pancreatic duct $>10 \mathrm{~mm}$ ) should be considered for surgery. ${ }^{49}$ On the other hand, cysts with WFs are observed by EUS and fine-needle aspiration. In lesions with WFs, main duct involvement, high-grade dysplasia, or confirmation of a mural nodule $>5 \mathrm{~mm}$ favors surgical resection. ${ }^{72}$ A recent systematic review included low-risk and non-low-risk (WF and high-risk stigmata) patients to find 10-year progression risks of low-risk IPMNs and higher-risk IPMNs to be $8 \%$ and $25 \%$, respectively. ${ }^{73}$ These studies were based on general populations, but data to guide a threshold for resection among HRIs are lacking.
If selected, surgical resection must be performed at highvolume centers with lower operative mortality and morbidity. ${ }^{74}$ The choice of surgery for lesions in HRIs is not completely clear. Although total pancreatectomy yields no risk of recurrence, it can result in brittle diabetes and exocrine insufficiency and necessitates lifestyle changes. Perioperative outcomes of total pancreatectomy versus partial pancreatectomy are variable. Also, curative resection aims to attain gross as well as microscopically negative margins. Although survival seems not to be influenced by PanIN (even high grade) at the margins, it is decreased by residual invasive cancer. ${ }^{75}$ In this setting, intraoperative frozen section finds utility, although accompanied with challenges of grading the PanINs.

\section{Outcomes of Screening Programs}

The CAPS Consortium defines successful screening by the detection and treatment of high-grade lesions, including PanIN-3, IPMNs, MCNs with high-grade dysplasia, and early resectable T1N0M0 margin-negative pancreatic cancer. Patient information, screening modalities, and outcome measures of various screening studies are shown (Table 3). ${ }^{53,61,71,76-93}$

\section{Survival Benefit}

It is imperative to determine whether a survival benefit exists for patients undergoing pancreatic cancer screening. A systematic review evaluated the benefits of screening programs among HRIs and revealed higher rates of curative resection $(60 \%$ versus $25 \% ; P=0.011)$ and prolonged survival (14.5 versus 4 months; $P<0.001) .{ }^{94}$ However, no significant differences in outcomes were seen in patients with IPMNs undergoing surgery. Whether increased survival merely reflects diagnosis earlier in the disease process or represents a truly extended lifespan is currently not established.

\section{Psychological Stress}

Psychological stressors associated with screening include perceived mortality risk, cancer-related anxiety, procedural discomfort, and emotional distress, especially for screened individuals, who turn out to have false-positive results. Higher perceived risk has been observed among familial pancreatic cancer family members compared with $B R C A 2$ mutation carriers. ${ }^{95}$ Interestingly, some studies have shown that perceived risk, cancer-related worries, intrusive thoughts, and anxiety toward the next procedure have a tendency to decline over time. ${ }^{95}$ A study by Harinck et $\mathrm{al}^{96}$ found the level of clinical depression or anxiety in six respondents to be $9 \%$. Procedure-related discomfort was found in $14 \%$ and $15 \%$ of those undergoing EUS and MRI, respectively. No correlation was observed between cancerrelated worries and surveillance outcomes (pancreatectomy 
or shortening of surveillance intervals), and a favorable surveillance benefit/risk ratio $(88 \%)$ and feasibility were demonstrated. ${ }^{96}$ Levels of anxiety and depression are not well defined for false-positive testing individuals.

\section{Limitations of Screening}

Numerous questions regarding PDAC screening in HRIs remain unanswered. Although current imaging modalities are sensitive for the early detection of cystic lesions, PanIN lesions require better characterization for early diagnosis, because they are not easily visualized through regular imaging. Biomarkers are actively sought, but the required exquisite specificity for general screening has kept them elusive for the moment. The preferred screening modality and interval of follow-up among an initially screened population remain to be established. The target population for PDAC screening is still uncertain. In addition, prediction models for PDAC based on the interaction of modifiable and genetic risk factors are required for further identification of the target population. HRIs comprise only approximately $10 \%$ of PDAC patients, and early detection of sporadic pancreatic cancers among individuals with no apparent predispositions has only been recently addressed. ${ }^{97}$

\section{Future Prospects}

Early diagnosis of PDAC will require better biomarkers or panels of biomarkers and more robust imaging protocols. These improvements are needed to prevent overdiagnosis of clinically nonsignificant lesions as well as omission of significant precursors or early PDACs. These screening and diagnostic modalities will involve simultaneous exploration, such that they enhance and validate one another. However, it seems unlikely that a biomarker panel with specificity $>99.9 \%$ for precursor lesions or early cancer, as would be needed for general population screening, will be found in the foreseeable future; such accuracies have only been observed for markers of infectious diseases but not for cancers.

The surveillance programs to date have been limited to only research settings, and their more general applicability is presently uncertain. Much attention in PDAC screening outcomes has concerned survival benefit, but other important considerations include surgical morbidity, postoperative quality of life, and psychological stress. In randomized studies, control subjects may not be feasible; prospective studies will need to use larger study samples and longer lengths of follow-up, and particularly have access to cohorts with stored biosamples taken throughout the duration of follow-up.

Recently, National Institute of Health and Care Excellence guidelines for pancreatic cancer were introduced for PDAC surveillance among HRIs (https://www.nice. org.uk/guidance/ng85/chapter/Recommendations\#people-withinherited-high-risk-of-pancreatic-cancer, last accessed
September 29, 2018). These guidelines differ from CAPS guidelines, especially in the management of individuals with HP. With further exploration of diagnostic modalities, better understanding of risk factors, and appraisal of available data, the hope is to fill essential knowledge gaps and find an international consensus on optimal management of these at-risk populations.

\section{Acknowledgment}

We thank D. Evan Kanouse for generating Figure 1.

\section{References}

1. Siegel RL, Miller KD, Jemal A: Cancer statistics, 2018. CA Cancer J Clin 2018, 68:7-30

2. Rahib L, Smith BD, Aizenberg R, Rosenzweig AB, Fleshman JM, Matrisian LM: Projecting cancer incidence and deaths to 2030: the unexpected burden of thyroid, liver, and pancreas cancers in the United States. Cancer Res 2014, 74:2913-2921

3. Neoptolemos JP, Palmer DH, Ghaneh P, Psarelli EE, Valle JW, Halloran CM, Faluyi O, O'Reilly DA, Cunningham D, Wadsley J, Darby S, Meyer T, Gillmore R, Anthoney A, Lind P, Glimelius B, Falk S, Izbicki JR, Middleton GW, Cummins S, Ross PJ, Wasan H, McDonald A, Crosby T, Ma YT, Patel K, Sherriff D, Soomal R, Borg D, Sothi S, Hammel P, Hackert T, Jackson R, Buchler MW; European Study Group for Pancreatic Cancer: Comparison of adjuvant gemcitabine and capecitabine with gemcitabine monotherapy in patients with resected pancreatic cancer (ESPAC-4): a multicentre, open-label, randomised, phase 3 trial. Lancet 2017, 389:1011-1024

4. Yachida S, Jones S, Bozic I, Antal T, Leary R, Fu B, Kamiyama M Hruban RH, Eshleman JR, Nowak MA, Velculescu VE, Kinzler KW, Vogelstein B, Iacobuzio-Donahue CA: Distant metastasis occurs late during the genetic evolution of pancreatic cancer. Nature 2010, 467: $1114-1117$

5. Wentzensen N, Wacholder S: From differences in means between cases and controls to risk stratification: a business plan for biomarker development. Cancer Discov 2013, 3:148-157

6. Risch HA, Lu L, Wang J, Zhang W, Ni Q, Gao Y-T, Yu H: ABO blood group and risk of pancreatic cancer: a study in Shanghai and meta-analysis. Am J Epidemiol 2013, 177:1326-1337

7. Brand RE, Lerch MM, Rubinstein WS, Neoptolemos JP Whitcomb DC, Hruban RH, Brentnall TA, Lynch HT, Canto MI; Participants of the Fourth International Symposium of Inherited Diseases of the Pancreas: Advances in counselling and surveillance of patients at risk for pancreatic cancer. Gut 2007, 56:1460-1469

8. Klein AP, Brune KA, Petersen GM, Goggins M, Tersmette AC Offerhaus GJA, Griffin C, Cameron JL, Yeo CJ, Kern S, Hruban RH: Prospective risk of pancreatic cancer in familial pancreatic cancer kindreds. Cancer Res 2004, 64:2634-2638

9. Grover S, Syngal S: Hereditary pancreatic cancer. Gastroenterology 2010, 139:1076-1080.e2

10. Brune KA, Lau B, Palmisano E, Canto M, Goggins MG, Hruban RH, Klein AP: Importance of age of onset in pancreatic cancer kindreds. J Natl Cancer Inst 2010, 102:119-126

11. D'Andrea AD, Grompe M: The Fanconi anaemia/BRCA pathway. Nat Rev Cancer 2003, 3:23-34

12. Breast Cancer Linkage Consortium: Cancer risks in BRCA2 mutation carriers. J Natl Cancer Inst 1999, 91:1310-1316

13. van Asperen CJ, Brohet RM, Meijers-Heijboer EJ, Hoogerbrugge N, Verhoef S, Vasen HFA, Ausems MGEM, Menko FH, Gomez Garcia EB, Klijn JGM, Hogervorst FBL, van Houwelingen JC, van't Veer LJ, Rookus MA, van Leeuwen FE; Netherlands Collaborative 
Group on Hereditary Breast Cancer (HEBON): Cancer risks in BRCA2 families: estimates for sites other than breast and ovary. J Med Genet 2005, 42:711-719

14. Brose MS: Cancer risk estimates for BRCA1 mutation carriers identified in a risk evaluation program. J Natl Cancer Inst 2002, 94: $1365-1372$

15. Thompson D, Easton DF; Breast Cancer Linkage Consortium: Cancer incidence in BRCA1 mutation carriers. J Natl Cancer Inst 2002, 94: 1358-1365

16. Murphy KM, Brune KA, Griffin C, Sollenberger JE, Petersen GM, Bansal R, Hruban RH, Kern SE: Evaluation of candidate genes MAP2K4, MADH4, ACVR1B, and BRCA2 in familial pancreatic cancer: deleterious BRCA2 mutations in 17\%. Cancer Res 2002, 62 : 3789-3793

17. Risch HA, McLaughlin JR, Cole DEC, Rosen B, Bradley L, Fan I, Tang J, Li S, Zhang S, Shaw PA, Narod SA: Population BRCA1 and BRCA2 mutation frequencies and cancer penetrances: a kin-cohort study in Ontario, Canada. J Natl Cancer Inst 2006, 98:1694-1706

18. Guo Y, Feng W, Sy SM, Huen MS: ATM-dependent phosphorylation of the Fanconi anemia protein PALB2 promotes the DNA damage response. J Biol Chem 2015, 290:27545-27556

19. Casadei S, Norquist BM, Walsh T, Stray S, Mandell JB, Lee MK, Stamatoyannopoulos JA, King MC: Contribution of inherited mutations in the BRCA2-interacting protein PALB2 to familial breast cancer. Cancer Res 2011, 71:2222-2229

20. de Snoo FA, Bishop DT, Bergman W, van Leeuwen I, van der Drift C, van Nieuwpoort FA, Out-Luiting CJ, Vasen HF, ter Huurne JAC, Frants RR, Willemze R, Breuning MH, Gruis NA: Increased risk of cancer other than melanoma in CDKN2A founder mutation (p16-Leiden)-positive melanoma families. Clin Cancer Res $2008,14: 7151-7157$

21. Kastrinos F, Mukherjee B, Tayob N, Wang F, Sparr J, Raymond VM, Bandipalliam P, Stoffel EM, Gruber SB, Syngal S: Risk of pancreatic cancer in families with Lynch syndrome. JAMA 2009, 302: $1790-1795$

22. Jenne DE, Reimann H, Nezu J, Friedel W, Loff S, Jeschke R, Müller O, Back W, Zimmer M: Peutz-Jeghers syndrome is caused by mutations in a novel serine threonine kinase. Nat Genet 1998, 18: $38-43$

23. Giardiello FM, Brensinger JD, Tersmette AC, Goodman SN, Petersen GM, Booker SV, Cruz-Correa M, Offerhaus JA: Very high risk of cancer in familial Peutz-Jeghers syndrome. Gastroenterology 2000, 119:1447-1453

24. Galiatsatos P, Foulkes WD: Familial adenomatous polyposis. Am J Gastroenterol 2006, 101:385-398

25. Roberts NJ, Jiao Y, Yu J, Kopelovich L, Petersen GM, Bondy ML, Gallinger S, Schwartz AG, Syngal S, Cote ML, Axilbund J, Schulick R, Ali SZ, Eshleman JR, Velculescu VE, Goggins M, Vogelstein B, Papadopoulos N, Hruban RH, Kinzler KW, Klein AP: ATM mutations in patients with hereditary pancreatic cancer. Cancer Discov 2011, 2:41-46

26. Swift M, Chase CL, Morrell D: Cancer predisposition of ataxiatelangiectasia heterozygotes. Cancer Genet Cytogenet 1990, 46: $21-27$

27. Howes N, Lerch MM, Greenhalf W, Stocken DD, Ellis I, Simon P, Truninger K, Ammann R, Cavallini G, Charnley RM, Uomo G, Delhaye M, Spicak J, Drumm B, Jansen J, Mountford R, Whitcomb DC, Neoptolemos JP; European Registry of Hereditary Pancreatitis and Pancreatic Cancer (EUROPAC): Clinical and genetic characteristics of hereditary pancreatitis in Europe. Clin Gastroenterol Hepatol 2004, 2:252-261

28. Lowenfels AB, Maisonneuve P, DiMagno EP, Elitsur Y, Gates LK Jr, Perrault J, Whitcomb DC; International Hereditary Pancreatitis Study Group: Hereditary pancreatitis and the risk of pancreatic cancer. J Natl Cancer Inst 1997, 89:442-446

29. Maisonneuve P, Marshall BC, Lowenfels AB: Risk of pancreatic cancer in patients with cystic fibrosis. Gut 2007, 56:1327-1328
30. Iodice S, Gandini S, Maisonneuve P, Lowenfels AB: Tobacco and the risk of pancreatic cancer: a review and meta-analysis. Langenbecks Arch Surg 2008, 393:535-545

31. Duell EJ: Epidemiology and potential mechanisms of tobacco smoking and heavy alcohol consumption in pancreatic cancer. Mol Carcinog 2012, 51:40-52

32. Rulyak SJ, Lowenfels AB, Maisonneuve P, Brentnall TA: Risk factors for the development of pancreatic cancer in familial pancreatic cancer kindreds. Gastroenterology 2003, 124:1292-1299

33. Lowenfels $\mathrm{AB}$, Maisonneuve $\mathrm{P}$, Whitcomb DC, Lerch MM, DiMagno EP: Cigarette smoking as a risk factor for pancreatic cancer in patients with hereditary pancreatitis. JAMA 2001, 286:169-170

34. Wang Y-T, Gou Y-W, Jin W-W, Xiao M, Fang H-Y: Association between alcohol intake and the risk of pancreatic cancer: a doseresponse meta-analysis of cohort studies. BMC Cancer 2016, 16:212

35. Risch HA: Diabetes and pancreatic cancer: both cause and effect. J Natl Cancer Inst 2018, djy093

36. Permert J, Ihse I, Jorfeldt L, von Schenck H, Arnquist HJ, Larsson J: Improved glucose metabolism after subtotal pancreatectomy for pancreatic cancer. Br J Surg 1993, 80:1047-1050

37. Hart PA, Baichoo E, Bi Y, Hinton A, Kudva YC, Chari ST: Pancreatic polypeptide response to a mixed meal is blunted in pancreatic head cancer associated with diabetes mellitus. Pancreatology 2015, 15:162-166

38. Sah RP, Nagpal SJS, Mukhopadhyay D, Chari ST: New insights into pancreatic cancer-induced paraneoplastic diabetes. Nat Rev Gastroenterol Hepatol 2013, 10:423-433

39. Andersen DK, Korc M, Petersen GM, Eibl G, Li D, Rickels MR, Chari ST, Abbruzzese JL: Diabetes, pancreatogenic diabetes, and pancreatic cancer. Diabetes 2017, 66:1103-1110

40. Andersen DK, Andren-Sandberg Å, Duell EJ, Goggins M, Korc M, Petersen GM, Smith JP, Whitcomb DC: Pancreatitis - diabetes pancreatic cancer: summary of an NIDDK-NCI workshop. Pancreas 2013, 42:1227-1237

41. Lowenfels AB, Maisonneuve P, Cavallini G, Ammann RW, Lankisch PG, Andersen JR, Dimagno EP, Andrén-Sandberg A, Domellöf L; International Pancreatitis Study Group: Pancreatitis and the risk of pancreatic cancer. N Engl J Med 1993, 328:1433-1437

42. Raimondi S, Lowenfels AB, Morselli-Labate AM, Maisonneuve P, Pezzilli R: Pancreatic cancer in chronic pancreatitis: aetiology, incidence, and early detection. Best Pract Res Clin Gastroenterol 2010, 24:349-358

43. Hao L, Zeng X-P, Xin L, Wang D, Pan J, Bi Y-W, Ji J-T, Du T-T, Lin JH, Zhang D, Ye B, Zou W-B, Chen H, Xie T, Li B-R, Zheng Z-H, Wang T, Guo H-L, Liao Z, Li Z-S, Hu L-H: Incidence of and risk factors for pancreatic cancer in chronic pancreatitis: a cohort of 1656 patients. Dig Liver Dis 2017, 49:1249-1256

44. Canto MI, Harinck F, Hruban RH, Offerhaus GJ, Poley J-W, Kamel I, Nio Y, Schulick RS, Bassi C, Kluijt I, Levy MJ, Chak A, Fockens P, Goggins M, Bruno M; International Cancer of Pancreas Screening (CAPS) Consortium: International Cancer of the Pancreas Screening (CAPS) Consortium summit on the management of patients with increased risk for familial pancreatic cancer. Gut 2013, 62:339-347

45. Brat DJ, Lillemoe KD, Yeo CJ, Warfield PB, Hruban RH: Progression of pancreatic intraductal neoplasias to infiltrating adenocarcinoma of the pancreas. Am J Surg Pathol 1998, 22:163-169

46. Valsangkar NP, Morales-Oyarvide V, Thayer SP, Ferrone CR, Wargo JA, Warshaw AL, Fernández-del Castillo C: 851 Resected cystic tumors of the pancreas: a 33-year experience at the Massachusetts General Hospital. Surgery 2012, 152:S4-S12

47. Yamao K, Yanagisawa A, Takahashi K, Kimura W, Doi R, Fukushima N, Ohike N, Shimizu M, Hatori T, Nobukawa B, Hifumi M, Kobayashi Y, Tobita K, Tanno S, Sugiyama M, Miyasaka Y, Nakagohri T, Yamaguchi T, Hanada K, Abe H, Tada M, Fujita N, Tanaka M: Clinicopathological features and prognosis of mucinous cystic neoplasm with ovarian-type stroma: a 
multi-institutional study of the Japan pancreas society. Pancreas 2011, 40:67-71

48. Levy P, Jouannaud V, Otoole D, Couvelard A, Vullierme M, Palazzo L, Aubert A, Ponsot P, Sauvanet A, Maire F: Natural history of intraductal papillary mucinous tumors of the pancreas: actuarial risk of malignancy. Clin Gastroenterol Hepatol 2006, 4:460-468

49. Kim TH, Song TJ, Hwang J-H, Yoo K-S, Lee W-J, Lee K-H, Dong S-H, Park C-H, Park E-T, Moon J-H, Kim H-G, Kim E-Y, Cho KB, Kim H-J, Lee S-O, Cheon YK, Lee JM, Oh DW, Kim M-H: Predictors of malignancy in pure branch duct type intraductal papillary mucinous neoplasm of the pancreas: a nationwide multicenter study. Pancreatology 2015, 15:405-410

50. Kang MJ, Jang J-Y, Kim SJ, Lee KB, Ryu JK, Kim Y-T, Yoon YB, Kim S-W: Cyst growth rate predicts malignancy in patients with branch duct intraductal papillary mucinous neoplasms. Clin Gastroenterol Hepatol 2011, 9:87-93

51. Kwong WT, Lawson RD, Hunt G, Fehmi SM, Proudfoot JA, Xu R, Giap A, Tang RS, Gonzalez I, Krinsky ML, Savides TJ: Rapid growth rates of suspected pancreatic cyst branch duct intraductal papillary mucinous neoplasms predict malignancy. Dig Dis Sci 2015, 60:2800-2806

52. Hruban RH, Takaori K, Klimstra DS, Adsay NV, Albores-Saavedra J, Biankin AV, Biankin SA, Compton C, Fukushima N, Furukawa T, Goggins M, Kato Y, Klöppel G, Longnecker DS, Lüttges J, Maitra A, Offerhaus GJA, Shimizu M, Yonezawa S: An illustrated consensus on the classification of pancreatic intraepithelial neoplasia and intraductal papillary mucinous neoplasms. Am J Surg Pathol 2004, 28: 977-987

53. Canto MI, Hruban RH, Fishman EK, Kamel IR, Schulick R, Zhang Z, Topazian M, Takahashi N, Fletcher J, Petersen G, Klein AP, Axilbund J, Griffin C, Syngal S, Saltzman JR, Mortele KJ, Lee J, Tamm E, Vikram R, Bhosale P, Margolis D, Farrell J, Goggins M: Frequent detection of pancreatic lesions in asymptomatic high-risk individuals. Gastroenterology 2012, 142:796-804

54. Ulrich CD; Consensus Committees of the European Registry of Hereditary Pancreatic Diseases; Midwest Multi-Center Pancreatic Study Group; International Association of Pancreatology: Pancreatic cancer in hereditary pancreatitis: consensus guidelines for prevention, screening and treatment. Pancreatology 2001, 1:416-422

55. Kaneko OF, Lee DM, Wong J, Kadell BM, Reber HA, Lu DSK, Raman SS: Performance of multidetector computed tomographic angiography in determining surgical resectability of pancreatic head adenocarcinoma. J Comput Assist Tomogr 2010, 34:732-738

56. Rijkers AP, Valkema R, Duivenvoorden HJ, van Eijck CHJ: Usefulness of F-18-fluorodeoxyglucose positron emission tomography to confirm suspected pancreatic cancer: a meta-analysis. Eur J Surg Oncol 2014, 40:794-804

57. Adamek HE, Albert J, Breer H, Weitz M, Schilling D, Riemann JF: Pancreatic cancer detection with magnetic resonance cholangiopancreatography and endoscopic retrograde cholangiopancreatography: a prospective controlled study. Lancet 2000, 356:190-193

58. Robertis RD, De Robertis R: Diffusion-weighted imaging of pancreatic cancer. World J Radiol 2015, 7:319

59. Niu X-K, Bhetuwal A, Das S, Xiao Y-Q, Sun F, Zeng L-C, Yang HF: Meta-analysis of quantitative diffusion-weighted MR imaging in differentiating benign and malignant pancreatic masses. J Huazhong Univ Sci Technolog Med Sci 2014, 34:950-956

60. Topazian M, Enders F, Kimmey M, Brand R, Chak A, Clain J, Cunningham J, Eloubeidi M, Gerdes H, Gress F, Jagannath S, Kantsevoy S, LeBlanc JK, Levy M, Lightdale C, Romagnuolo J, Saltzman JR, Savides T, Wiersema M, Woodward T, Petersen G, Canto M: Interobserver agreement for EUS findings in familial pancreatic-cancer kindreds. Gastrointest Endosc 2007, 66:62-67

61. Harinck F, Konings ICAW, Kluijt I, Poley JW, van Hooft JE, van Dullemen HM, Nio CY, Krak NC, Hermans JJ, Aalfs CM, Wagner A, Sijmons RH, Biermann $\mathrm{K}$, van Eijck $\mathrm{CH}$, Gouma DJ, Dijkgraaf MGW, Fockens P, Bruno MJ; Dutch research group on pancreatic cancer surveillance in high-risk individuals: A multicentre comparative prospective blinded analysis of EUS and MRI for screening of pancreatic cancer in high-risk individuals. Gut 2016, 65: $1505-1513$

62. Goggins M: Molecular markers of early pancreatic cancer. J Clin Oncol 2005, 23:4524-4531

63. Huang Z, Liu F: Diagnostic value of serum carbohydrate antigen 19-9 in pancreatic cancer: a meta-analysis. Tumour Biol 2014, 35: $7459-7465$

64. Bloomston M, Frankel WL, Petrocca F, Volinia S, Alder H, Hagan JP, Liu C-G, Bhatt D, Taccioli C, Croce CM: MicroRNA expression patterns to differentiate pancreatic adenocarcinoma from normal pancreas and chronic pancreatitis. JAMA 2007, 297:1901

65. Ho AS, Huang X, Cao H, Christman-Skieller C, Bennewith K, Le QT, Koong AC: Circulating miR-210 as a novel hypoxia marker in pancreatic cancer. Transl Oncol 2010, 3:109-113

66. Goto T, Fujiya M, Konishi H, Sasajima J, Fujibayashi S, Hayashi A, Utsumi T, Sato H, Iwama T, Ijiri M, Sakatani A, Tanaka K, Nomura Y, Ueno N, Kashima S, Moriichi K, Mizukami Y, Kohgo Y, Okumura T: An elevated expression of serum exosomal microRNA191, -21, -451a of pancreatic neoplasm is considered to be efficient diagnostic marker. BMC Cancer 2018, 18:116

67. Allenson K, Castillo J, San Lucas FA, Scelo G, Kim DU, Bernard V, Davis G, Kumar T, Katz M, Overman MJ, Foretova L, Fabianova E, Holcatova I, Janout V, Meric-Bernstam F, Gascoyne P, Wistuba I, Varadhachary G, Brennan P, Hanash S, Li D, Maitra A, Alvarez H: High prevalence of mutant KRAS in circulating exosome-derived DNA from early-stage pancreatic cancer patients. Ann Oncol 2017, 28:741-747

68. Cohen JD, Li L, Wang Y, Thoburn C, Afsari B, Danilova L, et al: Detection and localization of surgically resectable cancers with a multi-analyte blood test. Science 2018, 359:926-930

69. Chen R, Pan S, Yi EC, Donohoe S, Bronner MP, Potter JD, Goodlett DR, Aebersold R, Brentnall TA: Quantitative proteomic profiling of pancreatic cancer juice. Proteomics 2006, 6:3871-3879

70. Kanda M, Sadakari Y, Borges M, Topazian M, Farrell J, Syngal S, Lee J, Kamel I, Lennon AM, Knight S, Fujiwara S, Hruban RH, Canto MI, Goggins M: Mutant TP53 in duodenal samples of pancreatic juice from patients with pancreatic cancer or high-grade dysplasia. Clin Gastroenterol Hepatol 2013, 11:719-730.e5

71. Bartsch DK, Slater EP, Carrato A, Ibrahim IS, Guillen-Ponce C, Vasen HFA, Matthäi E, Earl J, Jendryschek FS, Figiel J, Steinkamp M, Ramaswamy A, Vázquez-Sequeiros E, MuñozBeltran M, Montans J, Mocci E, Bonsing BA, Wasser M, Klöppel G, Langer P, Fendrich V, Gress TM: Refinement of screening for familial pancreatic cancer. Gut 2016, 65:1314-1321

72. Tanaka M, Fernández-Del Castillo C, Kamisawa T, Jang JY, Levy P, Ohtsuka T, Salvia R, Shimizu Y, Tada M, Wolfgang CL: Revisions of international consensus Fukuoka guidelines for the management of IPMN of the pancreas. Pancreatology 2017, 17:738-753

73. Choi SH, Park SH, Kim KW, Lee JY, Lee SS: Progression of unresected intraductal papillary mucinous neoplasms of the pancreas to cancer: a systematic review and meta-analysis. Clin Gastroenterol Hepatol 2017, 15:1509-1520.e4

74. Finks JF, Osborne NH, Birkmeyer JD: Trends in hospital volume and operative mortality for high-risk surgery. N Engl J Med 2011, 364 : $2128-2137$

75. Matthaei H, Hong S-M, Mayo SC, dal Molin M, Olino K, Venkat R, Goggins M, Herman JM, Edil BH, Wolfgang CL, Cameron JL, Schulick RD, Maitra A, Hruban RH: Presence of pancreatic intraepithelial neoplasia in the pancreatic transection margin does not influence outcome in patients with R0 resected pancreatic cancer. Ann Surg Oncol 2011, 18:3493-3499

76. Brentnall TA, Bronner MP, Byrd DR, Haggitt RC, Kimmey MB: Early diagnosis and treatment of pancreatic dysplasia in patients with a family history of pancreatic cancer. Ann Intern Med 1999, 131: $247-255$ 
77. Rulyak SJ, Brentnall TA: Inherited pancreatic cancer: surveillance and treatment strategies for affected families. Pancreatology 2001, 1: 477-485

78. Kimmey MB, Bronner MP, Byrd DR, Brentnall TA: Screening and surveillance for hereditary pancreatic cancer. Gastrointest Endosc 2002, 56:S82-S86

79. Canto MI, Goggins M, Yeo CJ, Griffin C, Axilbund JE, Brune K, Ali SZ, Jagannath S, Petersen GM, Fishman EK, Piantadosi S, Giardiello FM, Hruban RH: Screening for pancreatic neoplasia in high-risk individuals: an EUS-based approach. Clin Gastroenterol Hepatol 2004, 2:606-621

80. Canto MI, Goggins M, Hruban RH, Petersen GM, Giardiello FM, Yeo C, Fishman EK, Brune K, Axilbund J, Griffin C, Ali S, Richman J, Jagannath S, Kantsevoy SV, Kalloo AN: Screening for early pancreatic neoplasia in high-risk individuals: a prospective controlled study. Clin Gastroenterol Hepatol 2006, 4:766-781; quiz 665

81. Poley JW, Kluijt I, Gouma DJ, Harinck F, Wagner A, Aalfs C, van Eijck CHJ, Cats A, Kuipers EJ, Nio Y, Fockens P, Bruno MJ: The yield of first-time endoscopic ultrasonography in screening individuals at a high risk of developing pancreatic cancer. Am J Gastroenterol 2009, 104:2175-2181

82. Langer P, Kann PH, Fendrich V, Habbe N, Schneider M, Sina M, Slater EP, Heverhagen JT, Gress TM, Rothmund M, Bartsch DK: Five years of prospective screening of high-risk individuals from families with familial pancreatic cancer. Gut 2009, 58:1410-1418

83. Verna EC, Hwang C, Stevens PD, Rotterdam H, Stavropoulos SN, Sy CD, Prince MA, Chung WK, Fine RL, Chabot JA, Frucht H: Pancreatic cancer screening in a prospective cohort of high-risk patients: a comprehensive strategy of imaging and genetics. Clin Cancer Res 2010, 16:5028-5037

84. Ludwig E, Olson SH, Bayuga S, Simon J, Schattner MA, Gerdes H, Allen PJ, Jarnagin WR, Kurtz RC: Feasibility and yield of screening in relatives from familial pancreatic cancer families. Am J Gastroenterol 2011, 106:946-954

85. Schneider R, Slater EP, Sina M, Habbe N, Fendrich V, Matthäi E, Langer P, Bartsch DK: German national case collection for familial pancreatic cancer (FaPaCa): ten years experience. Fam Cancer 2011, 10:323-330

86. Vasen HFA, Wasser M, van Mil A, Tollenaar RA, Konstantinovski M, Gruis NA, Bergman W, Hes FJ, Hommes DW, Offerhaus GJA, Morreau H, Bonsing BA, de Vos tot Nederveen Cappel WH: Magnetic resonance imaging surveillance detects earlystage pancreatic cancer in carriers of a p16-Leiden mutation. Gastroenterology 2011, 140:850-856

87. Al-Sukhni W, Borgida A, Rothenmund H, Holter S, Semotiuk K, Grant R, Wilson S, Moore M, Narod S, Jhaveri K, Haider MA, Gallinger S: Screening for pancreatic cancer in a high-risk cohort: an eight-year experience. J Gastrointest Surg 2012, 16:771-783

88. Potjer TP, Schot I, Langer P, Heverhagen JT, Wasser MNJM, Slater EP, Klöppel G, Morreau HM, Bonsing BA, de Vos Tot Nederveen Cappel WH, Bargello M, Gress TM, Vasen HFA,
Bartsch DK; Leiden Familial Pancreatic Cancer Group; FaPaCa registry: Variation in precursor lesions of pancreatic cancer among high-risk groups. Clin Cancer Res 2013, 19:442-449

89. Sud A, Wham D, Catalano M, Guda NM: Promising outcomes of screening for pancreatic cancer by genetic testing and endoscopic ultrasound. Pancreas 2014, 43:458-461

90. Del Chiaro M, Verbeke CS, Kartalis N, Pozzi Mucelli R, Gustafsson P, Hansson J, Haas SL, Segersvärd R, AndrenSandberg Å, Löhr JM: Short-term results of a magnetic resonance imaging-based Swedish screening program for individuals at risk for pancreatic cancer. JAMA Surg 2015, 150:512-518

91. Mocci E, Guillen-Ponce C, Earl J, Marquez M, Solera J, SalazarLópez MT, Calcedo-Arnáiz C, Vázquez-Sequeiros E, Montans J, Muñoz-Beltrán M, Vicente-Bártulos A, González-Gordaliza C, Sanjuanbenito A, Guerrero C, Mendía E, Lisa E, Lobo E, Martínez JC, Real FX, Malats N, Carrato A: PanGen-Fam: Spanish registry of hereditary pancreatic cancer. Eur J Cancer 2015, 51: 1911-1917

92. Vasen H, Ibrahim I, Ponce CG, Slater EP, Matthäi E, Carrato A, Earl J, Robbers K, van Mil AM, Potjer T, Bonsing BA, de Vos Tot Nederveen Cappel WH, Bergman W, Wasser M, Morreau H, Klöppel G, Schicker C, Steinkamp M, Figiel J, Esposito I, Mocci E, Vazquez-Sequeiros E, Sanjuanbenito A, Muñoz-Beltran M, Montans J, Langer P, Fendrich V, Bartsch DK: Benefit of surveillance for pancreatic cancer in high-risk individuals: outcome of longterm prospective follow-up studies from three European expert centers. J Clin Oncol 2016, 34:2010-2019

93. Konings ICAW, Harinck F, Poley J-W, Aalfs CM, van Rens A, Krak NC, Wagner A, Nio CY, Sijmons RH, van Dullemen HM, Vleggaar FP, Ausems MGEM, Fockens P, van Hooft JE, Bruno MJ; Dutch Research Group on Pancreatic Cancer Surveillance in HighRisk Individuals: Prevalence and progression of pancreatic cystic precursor lesions differ between groups at high risk of developing pancreatic cancer. Pancreas 2017, 46:28-34

94. Lu C: Screening for pancreatic cancer in familial high-risk individuals: a systematic review. World J Gastroenterol 2015, 21:8678

95. Maheu C, Vodermaier A, Rothenmund H, Gallinger S, Ardiles P, Semotiuk K, Holter S, Thayalan S, Esplen MJ: Pancreatic cancer risk counselling and screening: impact on perceived risk and psychological functioning. Fam Cancer 2010, 9:617-624

96. Harinck F, Nagtegaal T, Kluijt I, Aalfs C, Smets E, Poley J-W, Wagner A, van Hooft J, Fockens P, Bruno M, Bleiker EMA: Feasibility of a pancreatic cancer surveillance program from a psychological point of view. Genet Med 2011, 13: 1015-1024

97. Chari ST, Kelly K, Hollingsworth MA, Thayer SP, Ahlquist DA, Andersen DK, Batra SK, Brentnall TA, Canto M, Cleeter DF, Firpo MA, Gambhir SS, Go VLW, Hines OJ, Kenner BJ, Klimstra DS, Lerch MM, Levy MJ, Maitra A, Mulvihill SJ, Petersen GM, Rhim AD, Simeone DM, Srivastava S, Tanaka M, Vinik AI, Wong D: Early detection of sporadic pancreatic cancer: summative review. Pancreas 2015, 44:693-712 